\title{
THE ALBINISM OF TIMUR, ZĀL, AND EDWARD THE GONFESSOR
}

by

\section{P. FROGGATT}

\section{INTRODUCTION}

HISTORICAL personages are often alleged to have suffered from certain diseases or disabilities. Sometimes there is good evidence for this, but sometimes when the evidence is examined one wonders how the belief originated. At least three historical characters, and one biblical one, are frequently referred to as albinos. Two of them, Edward the Confessor and Timur, were real people, one being a King of England and the other the most powerful of the medieval Tartar rulers; the third is a figure in Persian legend, Zāl. The albinism of the fourth, Noah, is examined elsewhere. ${ }^{1}$

Generalized albinism is a rare condition inherited as a Mendelian recessive. Although some variation in expression in the genotype occurs the phenotypical extremes share certain basic clinical characteristics. These are: (I) hair which is always white at birth but may become fair or straw coloured in adult life, (2) white skin which may redden but does not tan, (3) the characteristic eye findings of nystagmus, pale blue irides which give a marked red reflex, photophobia, often marked lacrimation, and some degree of defective vision usually quite severe.

For an individual to be confidently diagnosed as an albino from written descriptions, both the first and third of these must be mentioned. In the three cases under review careful clinical descriptions are not available and consequently some inferences are drawn. These are confined to the eyesight because albinism has no direct detrimental effect on the general physical and mental health, physique or expectation of life. The possibility of parental consanguinity is considered because, albinism being inherited as a rare Mendelian recessive, the incidence of kinship marriage amongst the parents of albinos is many times greater than that amongst the population as a whole.

TIMUR

Timur, the son of an impoverished local chieftain, was born in Kesh near Samarkand in A.D. I336. After an adventurous youth and many years of unsuccessful rebellion against the Jagatai descendants of the Genghis Khan dynasty who controlled the vast plains of central Asia on which Kesh is situated, Timur at last seized power and by 1369 had become undisputed head of a new Tartar empire with its capital at Samarkand. High military and organizational talent enabled him to combine ruthlessly efficient administration at home with continuously successful conquest abroad, and when he died in 1405 while hastening to join his armies for the carefully prepared invasion of China he held sovereignty over the greatest territorial empire of the time. 


\section{The Albinism of Timur, Zäl, and Edward the Confessor}

The colour of Timur's hair is usually described as 'white from youth'2 or even 'white from birth'; ${ }^{3}$ indeed Gibb is emphatic in referring to a Timur white-haired from childhood as the 'authentic version' ${ }^{4}$ Consequently Timur is often assumed to have been an albino, but the evidence is conflicting and will be examined in detail.

The fourteenth and fifteenth centuries were the golden years of Persian literature. The Habibus-Siyar lists over two hundred Persians who wrote chronicles, histories or biographies in this period, twenty-three during Timur's lifetime. ${ }^{5}$ Like Sultan Mahmud before him and Frederick the Great after, Timur coveted a reputation as a patron of letters, and throughout the expansionist period of his empire he pursued a definite policy of attracting scholars to Samarkand. The works of most of these writers ${ }^{6}$ are lost or deal with grammar, logic or metaphysics, but at least five authors who were eye-witnesses of Timur, and three near contemporaries, wrote histories. ${ }^{7}$ In addition two Europeans who met Timur have left descriptive narratives. ${ }^{8}$

\section{CONTEMPORARY EASTERN HISTORIANS}

Nizam-i-Shami. Nizam is the only chronicler to write a history of Timur during the latter's lifetime. It was Timur's custom to employ a retinue of amanuenses to record details of his campaigns, and Nizam, who voluntarily joined Timur's secretariat after the fall of Baghdad in 1393, so won the king's confidence that he was given the task of editing the official records. The resulting history, in Persian, was written between 1400 and $1404,{ }^{10}$ received Timur's approval, and forms the basis of most later accounts.

Sharuf-u-d'in Ali Yazdi. Sharuf-u-d'in is the best known historian of Timur. His history was written in 1424 and $1425 .{ }^{12}$ Like Nizam he travelled with Timur on the later campaigns. After the latter's death he joined the court of his successor and was eventually commissioned by Timur's grandson, Ibrahim Sultan, to write a thorough history. Sharuf-u-d'in relies on the authority of Nizam's narrative, on the Persian writings of Timur's secretaries and on the part legendary Uighur verse chronicles which Nizam ignores. ${ }^{13}$ His history, essentially a more florid and verbose enlargement of Nizam's, ${ }^{14}$ has been translated into most European languages, and is now the accepted authoritative contemporary version of Timur's exploits. ${ }^{15}$

Sharuf-u-d'in does not mention Timur's hair colour or eyesight, merely relating examples of his skill in arms. ${ }^{16}$

Hafiz-i-Abru. Like his more celebrated colleagues, Hafiz travelled widely throughout Asia with Timur's armies, standing high in the king's esteem and being a constant companion in the later years. After Timur's death he joined Shahrukh's court and wrote his history in 1426 dedicating it to Timur's grandson, Baisunghur, who had inherited the family passion for artistic patronage. ${ }^{17}$ Hafiz's chronicle, a great deal of which is borrowed from Nizam, ${ }^{18}$ is written in four volumes, the last two of which are lost. ${ }^{19}$ Together with 


\section{P. Froggatt}

Sharuf-u-d'in's history, it forms the main basis for the later, non-contemporary but more widely known work of Abd-ul-Razzak.

Ahmed-ibn-Arabshah. Captured as a youth by Timur at the sack of Damascus in I 400, Arabshah was taken to Samarkand where he lived until his captor's death. He is unique among contemporary biographers in that he was a bitter and implacable enemy of Timur, and his version of the Tartar's character is in vivid contrast to the laudatory and eulogistic descriptions of his colleagues. He writes of Timur as follows:

He was tall and of lofty stature ... big in brow and head, mighty in strength and courage, wonderful in nature, white in colour mixed with red, but not dark, stout of limb with broad shoulders, thick fingers, long legs, perfect build, long beard, dry hands, lame on the right side with eyes like candles, without brilliance, powerful in voice. ... . ${ }^{20}$

Alhacen. 'A companion of Timur and familiar of his conquests', Alhacen wrote a highly flattering narrative from a verbal rendering of which a French translation was made. ${ }^{21}$ Although the obscurity of the original must throw doubt on its authenticity, it is accepted by such authorities as Malcolm. ${ }^{22}$ Timur is portrayed as follows:

The Prince had within his eyes divine beauty. . . . The rest of his visage was courteous and well proportioned: he had but little hair on his chin: he did wear his hair long and curled, contrary to the custom of his country ... and he . . . was always in a manner bare-headed and said his mother came from the race of Samson for a mark whereof she advised him to honour long hair. This was the cause that made him respected of his men at arms . . . and verily they (the hairs) were of a dusky colour drawing towards a violet the most beautiful any eye could behold. ...

\section{FIFTEENTH CENTURY HISTORIANS}

Mirkhwand. Mirkhwand is principally known for his massive seven-book history which spans the period from the birth of the Prophet to the reign of Sultan Husayn. ${ }^{23}$ The last book was partly written by his grandson Kwandamir. Most facts relevant to Timur are translated and reproduced in Price, ${ }^{24}$ but there is no description of Timur's appearance and this part of the history is essentially a reproduction of Sharuf-u-d'in. ${ }^{25}$

Abd-ul-Razzak. Razzak settled at Shahrukh's court in 1437, and faithfully served Timur's successors being a particular confidant of Sultan Abu S'aid. For his history, written between 1465 and 1470 , he relied on the authority of Hafiz and Sharuf-u-d'in. ${ }^{26,}{ }^{27}$ Only extracts are available in translation. Although this narrative differs from that of Sharuf-u-d'in in certain statements of fact, ${ }^{28}$ Quatremère notes that in all matters concerning Timur the two accounts are strikingly similar. ${ }^{29}$ Other authors have published extracts of Razzak's work, ${ }^{30}$ but they nowhere suggest that he referred to Timur as whitehaired.

There were many other histories of the period but these two are of special importance, the former because it was the only authoritative Persian history readily available in Europe until the eighteenth century, and the latter because of the considerable reliance placed in its accuracy by nineteenth century writers, especially Hammer-Purgstall. 
THE EUROPEAN NARRATIVES

Of these de Clavijo's is the oldest. ${ }^{31}$ Ruy Gonsalez de Clavijo, a Spanish nobleman, was sent by Henry III of Castille as ambassador to Timur's court. The circumstances leading to this unusual mission deserve brief description.

In 1396 the crusading forces of Sigismund of Hungary were slaughtered by the Turks at Nicopolis and as a result Constantinople, heart of Christian Byzantium, lay virtually defenceless at Sultan Bayazid's feet. The Emperor Manuel, heir to the Caesars, in a desperate effort to save his heritage tried to rally support from the courts of Christendom and offered to surrender the Empire to his brother in exchange for a treaty with the Turks. His efforts were fruitless and in due course Constantinople was invested and would have fallen but for Timur who seized the opportunity afforded by the Sultan's preoccupation, invaded the eastern Ottoman dominions and completely annihilated the Turkish armies at Angora in 1402. The victory was complete. Bayazid, his treasure, his capital city, his harem, were all captured and his army decimated. Amongst those taken prisoner were two Spanish envoys and Angelina, daughter of Count John of Hungary, a reluctant member of the Sultan's harem. Timur treated these captives with great courtesy, allowing them to return to Spain and sending Muhammad al-Qadi to Castille as his personal representative.

The news of Angora was received with relief in the courts of Europe, several rulers, including Henry IV of England, sending Timur congratulatory letters. Henry of Castille, in appreciation for the courtesy shown to his envoys, desiring to acknowledge his gratitude for Bayazid's defeat, and in a genuine endeavour to establish official relations with the Tartars, despatched a representative to Timur, and Ruy Gonsalez de Clavijo with a small party sailed from Seville in May, 1403 on his long and dangerous journey. Presented in Samarkand some months later, de Glavijo describes Timur as '.. . an old man [whose] eyesight is bad, being so old that his eyelids have fallen down completely'. He was not totally blind for within a few months of this meeting he was in the field again as an active commander and in his leisure time was still fond of a game of chess. De Clavijo nowhere refers to Timur's colouring.

The other European narrative is by Johann Schiltberger, a Bavarian, born near Munich in $1381 .^{32}$ Leaving home to discharge his feudal duties he was captured at Nicopolis. His life was spared and he entered the services of the Sultan until the latter's defeat and capture after Angora. For the next three years he was a member of the Tartar horde and after Timur's death he travelled extensively in the East returning finally to Europe in 1427 . Schiltberger's narrative is brief, factual, and where confirmation is possible, accurate. His text deals with events rather than people and he does not describe Timur's appearance.

These accounts show little consistency. The consensus of evidence suggests that Timur was bearded, of fresh or pale complexion, with long hair possibly not dark. There is no assertion that his hair was ever white and in fact there is some evidence to the contrary. In old age his sight was bad, having bilateral ptosis, but there is presumptive evidence that during much of his life his sight was not seriously affected. 


\section{P. Froggatt}

\section{PICTORIAL EVIDENCE}

The oldest known portrait of Timur is by one of the last of the surviving artists of the Mongolian school and was drawn during Timur's lifetime. ${ }^{33}$ Some but not all authorities accept the identity of the subject. The oldest portrait in which Timur is unquestionably portrayed is by Bihzad and is from a MS dated 1467, over sixty years after Timur's death. A late sixteenth century portrait by the court painters of the Mogul Emperor Akbar,* and a portrait from the Shah Jahan period of the seventeenth century, are basically similar to the earlier versions allowing for stylistic differences. In none is Timur's hair white although Bihzad's representation shows the fair complexion to which his biographers refer. An engraving, allegedly of Timur, dates probably from the sixteenth century and is possibly German in origin. From the subject's physiognomy, arms and accoutrements it is clearly a Europeanized version and hardly to be considered an accurate likeness. ${ }^{34}$ Superficially it resembles Christopher Marlowe's Tamberlaine $\nmid$ from the play Tamberlaine the Great, first performed between 1588 and 1590 and in which Timur is portrayed as a ruthlessly efficient visionary with the following appearance (Act II, Sc. I, line 14):

... are fixed his piercing instruments of sight

Whose fiery circles bear encompassed,

A heaven of heavenly bodies in their spheres.

Pale of complexion wrought in him with passion,

Thirsting with sovereignty and love of arms,

His lofty brows in folds do figure death,

And in their smoothness amity and life;

About them hangs a knot of amber hair,

Wrapped in curls as fierce Achilles' was,

On which the breath of heaven delights to play.

(27) ... his arms and fingers long and sinewy,

Betokening valour and excess of strength,

In every way proportioned like a man,

Should make the world subdued to Tamberlaine.

Here the similarity ends. This engraving represents a type rather than a person; such an artistic style was common in the sixteenth century. Also Marlowe's version is probably a dramatic interpretation of Perondinus' description (Appendix I) and the whole an effort to establish a parallel with classical heroes; ${ }^{35}$ and in Marlowe's time 'amber' signified a pale yellowishbrown rather than the yellow-white it denotes today. None of the contemporary historical sources were available to Marlowe in original form and he drew his information mainly from Perondinus, ${ }^{36} \mathrm{Mexia}^{37}$ and Chalcondylas ${ }^{38}$ none of whom mentions red or white hair. The similarity as well as being superficial is therefore probably fortuitous. But the difficulty is that this passage contains many of the basic characteristics of albinism. Timur's hair is referred to as

\footnotetext{
* I am indebted to Shri S. A. Shere, Hon. Secretary of the Khuda Bakhsh O. P. Library, Patna, for this information.

+ Tamberlaine is a corruption of Timur-i-leng (Timur the lame).
} 


\section{The Albinism of Timur, Zäl, and Edward the Confessor}

'amber', his complexion as 'pale', his eyes 'piercing instruments of sight with fiery circles'. Also the last word of line 27 appears as 'snowy' and not 'sinewy' in the 1590 , I593 and 1597 editions, as 'snowy-white' in the $1605^{-6}$ edition, and was only changed to 'sinewy' by Dyce ${ }^{30}$ in 1850 as it seemed to be more meaningful than the original when taken in conjunction with the succeeding lines.

Marlowe's play, and perhaps the engraving, could each in their own way have contributed to the legend of Timur's albinism, but they cannot explain the origin of Timur's white hair on which the legend must be based. HammerPurgstall, the nineteenth century German authority, states bluntly 'Timur's hair, white from birth like that of the famous Zãl, contrasted oddly with the fresh bloom of his complexion'. ${ }^{40} \mathrm{He}$ does not give his authority for this statement, although it was from an Eastern source, and could not have obtained his information from any of the known extant contemporary narratives referred to above and could hardly have been influenced by Marlowe or stylized engravings. Nonetheless the idea of a white-haired Timur still exists in the East amongst the writers of Persian primers ${ }^{41}$ and has been accepted by experienced travellers in Asia. ${ }^{42}$ Its origin remains shadowy but there may have been an effort in verbal tradition in Persia and central Asia to establish an heroic parallel between Timur and Zāl.

Perhaps the last word should be from the grave. In 194I the Gur Amir mausoleum in Samarkand was opened and the interred remains established as Timur's from the pathological skeletal findings of tuberculous cavities in the right femur and tibia with bony fusion of the femur and patella, and complete bony ankylosis of the right humerus and ulna. It is established fact that during most of his adult life Timur was lame in the right leg and had a stiff right arm. ${ }^{43}$ The skull shows him to have been of Mongol-Indian racial type, and there is the remnants of a well-developed beard, dark chestnut in colour heavily streaked with grey. ${ }^{44}$ The discredited Alhacen, the bitter Arabshah and the imaginative Marlowe are nearest to the truth.

Two further questions remain; is there any evidence of consanguineous mating in Timur's parents and albinism amongst his sibs, or could Timur have been an albino with red hair and minimal ocular manifestations? Very little is known about Timur's family background but there is no evidence to suggest that he was the product of a close kinship mating or that any of his sibs were albinos. The second question is more difficult. Several authors describe cases with classical albino eye and skin findings but with red hair;45-8 therefore a red-haired albino genotype may occur. Photophobia due to hypopigmentation of the pigment epithelium of the eye together with absence of pigment from the uveal tract is a usual but by no means constant concomitant finding in albinism; indeed Pearson does not mention it when describing the chief clinical characteristics in the phenotype. ${ }^{49} \mathrm{It}$ can often be mollified by the adoption of an acquired ptosis giving the slit-eyed or 'moon-eyed' appearance referred to in even the earliest reports of the San Blas albinos. ${ }^{50}$ Timur's ptosis could be of this type. Failure to mention nystagmus is of more consequence. 


\section{P. Froggatt}

For reasons fully elaborated elsewhere ${ }^{51}$ the presence of nystagmus should probably be considered the ultimate criterion in albinism and its absence in the genotype extremely rare. Nevertheless exceptions occur. ${ }^{52-6}$ Timur may be atypical in this respect; if so, then the failure of his biographers to mention red pupils need not be considered as separate evidence against albinism as there is a positive correlation between the degree of nystagmus and the degree of ocular pigmentation, the latter being responsible for the intensity of the red reflex. This is because the early pigmentation of the optic cup, apparent by the fourth or fifth week of embryonic life, plays an important role in the normal differentiation of the choroid and retina and the consequent development of the macula lutea and fovea centralis. ${ }^{57} \mathrm{Up}$ to a point the same argument applies to the eyesight. Albinotic amblyopia is due to three main factors: $(a)$ hypoplasia of the macula and absence of the fovea, $(b)$ dazzling due to hypopigmentation of the normally pigmented structures of the eye, and $(c)$ refractive errors. Most albinos have quite severe visual impairment especially in strong light, but when the retina contains rather more pigment than is usual in albinism not only will the nystagmus be diminished but the acuity of vision will consequently improve and may even approach normality. For the same reasons photophobia will be greatly reduced, and for Timur to be an albino it need not necessarily be inferred that his poor sight and bilateral ptosis are albinotic in origin but may be allowed to be senile which is the more likely.

To argue that Timur was a genotypical albino with red hair and minimal eye involvement is valid but unrealistic.

\section{$Z \bar{A} \mathbf{L}$}

Zāl is an Arthurian figure of the Persian national epic. His life, his deeds, his appearance and his romance with Rudābāh are related in a massive epic poem, Shahnama, which took half a lifetime to write and was completed about A.D. IOro. ${ }^{1}$ The author, Abool-Kassim, was awarded the honour of adopting the name Ferdusi ('the poet from paradise') in appreciation of the beauty of this work. The principal sources for the poem are the prose 'Khuday-nāma originally written in Pahlawi and translated into Arabic in the eighth century, a Persian prose epic of the tenth century, ${ }^{2}$ and the rich oral traditions and legends of the country. The traditional story is that Zāl, son of a general in the army of Manuchakar, king of Persia, was born with snow-white hair

$$
\text { and cheeks with skin like the rose of spring. }{ }^{3,} \text {. }
$$

Because of this indignity he incurred the disfavour of his father and was abandoned on the dreaded mountain of Elburz where he was nursed by the Simurgh, a mythical bird of great size and wisdom, which in its own right maintains a place in Persian legend. Ultimately recovered by his father, Zāl grew to manhood, married Rudābāh the daughter of the king of Kabul, fathered Rustam the 'Persian Hercules', and when he died he left behind a reputation for bravery and chivalry surpassed only by his son. 


\section{The Albinism of Timur, Zäl, and Edward the Confessor}

There are numerous references in the poem to Zāl's hair and eyelashes being white at birth and remaining so throughout life. This is an essential criterion of albinism. His cheeks are 'like the rose of spring', and again 'ruddy as the flower of the Judas tree'; his lips are 'like coral'. These also are consistent with albinism for although albinotic skin is white due to the absence of melanin, it sometimes, especially on the face, appears red due to the colour of the blood in the dermal capillary beds being visible through the pigmentless epidermis. Ferdausi gives two distinct versions of Zāl's eye colour. The first is 'eyes . . . like two lustrous narcissi'. Here there is a translation difficulty as 'ābgūn', the word translated here as 'lustrous', can also mean blue or light coloured both of which are consistent with albinism. The second refers to his eyes as 'kir', the literal translation of which is 'pitch', which is at peculiar variance with the first description as well as being unsuggestive of an albino. Nowhere does Ferdausi mention red pupils, nystagmus, photophobia or amblyopia. That Zāl's white hair is his only fault is repeatedly stressed and

\section{$\ldots$ in vain would the fault-finder seek another defect.}

Due to the epic character of the poem and the quasi-legendary position of $Z$ āl it would be unreal to apply theoretical arguments for albinism to Ferdausi's description. It may be significant that apart from Timur's lameness there is a striking similarity between this description of Zāl and Hammer-Purgstall's of Timur. Despite the poet's opinion of white hair as a blemish and the initial disfavour which its possessor received, Persian mythology may not be opposed to accrediting heroes with this characteristic. If so then a real effort may have been made in oral tradition to equate Timur, a revered hero in Persian eyes, with this leading figure of their national epic. There is no reason to suppose that Ferdausi had an albino in mind when writing his poem or that Marlowe used one as a model when he could say

Should make the world subdued to Tamberlaine.

\section{EDWARD THE CONFESSOR}

Edward, the younger son of Ethelred the Unready and Emma of Normandy, became king of England in A.D. 1042 and died in 1066 in his early sixties.* Except for Harold, who succeeded him and who reigned for only a few months he was the last of the royal Saxon line to occupy the throne. He is variously described as 'almost an albino', 'seemingly an albino',2 ' . . . doubtless an albino', ${ }^{3}$ and more recently ' . . . according to tradition he was a kindly, weak, chubby albino'.4 Is there any evidence to justify these descriptions?

The only contemporary account of Edward's appearance extant is the Vita Eduardi Regis written by an unknown biographer between 1066 and 1074. ${ }^{5}$ The writer was certainly an eye-witness and may have been a monk from the

\footnotetext{
* Historians differ as to whether Edward or Alfred was the younger of the two sons of Ethelred and Emma. Here I have followed Freeman (Bibliography No. 3).
} 


\section{P. Froggatt}

Benedictine monastery of St. Peter at Westminster, and attached to the royal household. ${ }^{6} \mathrm{~A}$ translation is as follows:

As to his physical characteristics and outward appearance he was most handsome, of exceptional height distinguished by milk-white hair and beard, with a full face and rosy complexion. His hands were thin and snow-white, his fingers long and translucent. His whole body was free from blemish and he was every inch a king. He was agreeable yet preserved a proper seriousness, walking with lowered eyes and greeting everybody with the utmost affability. If roused to indignation by some just cause he was as fierce as a lion yet he did not vent his anger in abuse (see Appendix 1 ).

There are several phrases in this passage which are suggestive of albinism. Edward's hair is described as 'milk-white' but no intimation as to whether it was so at birth. This cannot be considered important as Edward may well have been middle-aged when the chronicler saw him. The writer adds that Edward had a chubby face with ruddy skin and long delicate white hands and fingers. This could be suggestive, the failure to comment on the skin of the rest of the body being unimportant as the writer can hardly be expected to have seen more than the exposed parts of the king's body, unless the phrase 'his whole body was free from blemish' is genuinely objective. The only reference to Edward's eyes is the phrase 'walking with lowered eyes (humiliatis incedens visibus)'. This may indicate photophobia but it is a phrase often used by medieval writers when referring to scholars or ecclesiatics. Nowhere are the conclusive ocular characteristics of the albino mentioned, and the sentence 'His whole body was free from blemish and he was every inch a king' suggests that they were absent or not evident. In addition Edward did not lead the sequestered existence which his soubriquet suggests. He had a great enthusiasm for hunting and the chase, pastimes usually requiring something better than albinotic vision.

If Edward's appearance as described in the Vita is allowed to be accurate there is not enough evidence to support a diagnosis of albinism unless similar arguments are used as with Timur. But is the Vita an accurate description? Throughout the narrative the king and his deeds are viewed in a highly sympathetic light surpassed only by the gross flattery reserved for Queen Edith and her family. This is understandable as the biographer was addressing himself to Edward's widow from whom, by his own admission, he had received considerable financial help in the past and perhaps hoped for her patronage again. The accuracy of the passage should be assessed with these facts in mind, and although the writer is broadly accurate in historical and chronological details any undesirable physical or mental trait which Edward possessed is unlikely to be stressed even if mentioned.

No other contemporary accounts are known. The later chronicles, i.e. those of the twelfth century by William of Malmesbury, Osbert of Westminster, and Aelred of Rievaulx, ${ }^{7}$ and that of the thirteenth century by an anonymous chronicler and dedicated to Eleanor of Provence, ${ }^{8}$ are of little assistance as they borrow extensively from the original manuscript, except that Malmesbury describes the king's skin as 'white all over (toto corpore lacteus)'.

$$
33^{6}
$$


Two further points are worth consideration. Edward had a legendary reputation for performing miracles of healing. He was the original 'toucher' for the 'King's Evil'; but it was in curing the blind that he achieved his greatest fame. Any supposition that he was given this gift because of a defect in his own sight appears to be groundless, as the thirteenth century writer says: ' . . that he had a soul so clear and pure that he should be able to enlighten the darkened and thus to cure the blind'.

The second point is the absence of any close consanguinity between the Confessor's parents which does not exclude the possibility of albinism but is not in its favour (Appendix 2). Even though the albinism gene is not randomly distributed in the population, remote kinship, which is possible but unlikely, is of no importance as the overall gene frequency in the population may be as high as $\mathrm{I} / 5^{\circ}$, this figure being calculated using the Hardy-Weinberg formula and a phenotype frequency of $\mathrm{I} / \mathrm{I} 0,000 .^{9} \mathrm{Also}$, if Edward were an albino then the probability of either his full brother or his full sister or both being affected is $0 \cdot 438$. Historical documentation of their appearance is scanty but there is no suggestion that either were albinos.

The difficulty in being categorical about Edward's albinism lies in the fact that only one eye-witness description, insufficient in clinical details and probably distorted, is extant. The evidence is insufficient to demand a definite conclusion but it is unjustifiable to refer to Edward as an albino.

\section{SUMM ARY}

Timur, Zāl and Edward the Confessor are sometimes referred to as albinos. The available evidence in each case is examined and in no instance is such a reference justified.

\section{NOTES AND BIBLIOGRAPHY}

\section{TIMUR}

1. Sorsby, A., Noah: An albino, Brit. med. F., 1958, ii, 1587 .

2. Bouva T, L., The Encyclopaedia of Islam, London, 1934, vol. rv, p. 779.

3. Hammer-Purgstall, J., Histoire del'Empire Ottoman, traduit par J-J. Hellert, Paris, Bellizard, Barthes, Dufont et Lowell, 1835 , vol. II, Bk. vir, p. 4.

4. Giв B, H. A. R., Encyclopaedia Britannica, London, 1957, vol. xxI, p. 232.

5. Browne, E. G., A Literary History of Persia, Cambridge University Press, 1928, vol. III, p. 421 .

6. BAR THOLD, W., Turkestan down to the Mongol Invasion, E. J. W. Gibb Memorial: (New Series no. 5), London, 1928, pp. 50 seq: and Browne, E. G., op. cit., vol. III, p. 354 seq.

7. The Egyptian historian, Ibn Khaldoun, met Timur after the sack of Damascus in 1400 , but left no eye-witness account of his appearance. For accounts of this meeting see Notices et Extraits des Manuscrips de la Bibliothèque du Roi, 1862; vol. XIX, pp. I-115, and Baron M. G. de Slane's translation of Ibn Khaldoun's biography in Asiatique, 4 ser., 3, 325-53.

8. For other lesser contemporary Eastern historians see Browne, E. G., op. cit., vol. III, p. 424 seq. 


\section{P. Froggatt}

9. Timur's Memoirs and Institutes are not considered as their authenticity is questioned. The various arguments are fully elaborated in Elliot, H. M., The History of India, edited by J. Dowson, London, 1872, vol. III, pp. 389 seq.; Rieu, C. P. H., Catalogue of Persian Manuscripts in the British Museum, London, British Museum, 1879, vol. I, p. 178.

10. RieU, C. P. H., op. cit., vol. I, p. I 70 .

II. The only complete MS of this work is in the British Museum (Add. 23, 980, Fol. 215). It has recently been edited by Felix Tauer in Prague in two volumes (1937 and 1957), and translated into Turkish by Necati Lugal (Ankara, 1949).

12. RIEU, C. P. H., op. cit., vol. I, p. 173 .

13. BARTHOLD, W., op. cit., p. 51 .

14. BROWNe, E. G., op. cit., vol. II, p. 361 .

15. Sharuf-u-d'in Ali, The History of Timur-Bec known as Tamerlain the Great, etc., 2 vols., translated into French by M. Petis de la Croix, and into English by John Darby, London, printed for J. Darby, E. Bell, W. Taylor, W. \& J. Innys, $\mathrm{J}$. Osborne and T, Payne, 1723 .

16. Mark ram, G. R., Narrative of the Embassy of Ruy Gonsalez de Clavijo to the Court of Timur at Samarkand, London, Hakluyt Society, 1859, p. L; VAMBERY, A., History of Bokhara, London, 1873, p. 194. Both quote Sharuf-u-d'in as referring to Timur as of ruddy and fair complexion, but I cannot find the original of this description in Darby's translation.

17. Martin, F. R., The Miniature Painting and Painters of Persia, India and Turkey from the eighth to the eighteenth Century, London, Bernard Quaritch, 1912, vol. I, p. 35 .

18. RIEU, G. P. H., op. cit., vol. I, p. 178 seq.

19. BROWNE, E. G., op. cit., vol. mi, p. 424.

20. Ahmed I BN ARABShah, Tamerlane, or Timur the Great Amir, translated by J. $\mathrm{H}$. Saunders, London, 1936, p. 295.

21. Almagen, Extracts of Alhacen his Arabike Historie of Tamerlan, touching his Martiall Travels, done into French by Jean du Bec, Abbat of Mortimer, in Hakluytus Posthumus or Purchas his Pilgrimes, Glasgow, 1906, vol. xI, pp. 40168.

22. Malcolm, J., The History of Persia from the most early period to the present time... 2 vols., London, John Murray and Longman \& Co., 1815, vol. I, p. 480.

23. BROWNe, E. G., op. cit., vol. II, p. 428.

24. PRICE, D., Chronological retrospect ... of Mohammedan History, London, J. Booth et al., I821, vol. III, pt. I, pp. 18-483.

25. VAMBERY, A., op. cit., p. I 79 (note).

26. BARTHOLD, W., op. cit., p. 56.

27. Appendix to MS (Add. 1 7,928, Foll. 379) in British Museum.

28. BARTHOLD, W., op. cit., p. 56.

29. QU A tremè Re, M., Noticeset Extraits des Manuscrits de la Bibliothèque du Roi, 1843, vol. xIv, pp. 12-13.

30. Elliot, H. M., op. cit., p. 91 seq; Vambéry, A., op. cit., p. 180 seq.

31. De Gravijo, R. G., Narrative of the Embassy of Ruy Gonsalez de Clavijo to the Court of Timur at Samarkand, translated by C. R. Markham, London, Hakluyt Society, 1859 .

32. Schiltberger, J., The Bondage and Travels of Johann Schiltberger, 1396-1427, translated by J. Buchan Telfer, London, Hakluyt Society, 1879 . 


\section{The Albinism of Timur, Zäl, and Edward the Confessor}

33. Martin, F. R., op. cit., vol. r, p. 26.

34. Reproduced in $A$ Concise History of the World, London, Associated Newspapers Ltd., 1935, p. 312. I have been unable to trace the provenance of this engraving, and I am obliged to Dr. Leo Ettlinger, Warburg Institute, and Mr. Christopher White, British Museum, for the information appearing in the text.

35. Ellis-Fermor, U. M., 'Tamburlaine the Great', by Christopher Marlowe, edited by U. M. Ellis-Fermor, London, Methuen \& Co., 1930, p. 93 (note).

36. Perondinus, P., The Life of the Great Tamerlane, Emperor of Scythia, Florence, I553, chap. 21 .

37. Mexia, P., The Foreste; or, Collection of Histories no less profitable, than pleasant and necessarie, dooen out of Frenche into Englishe by T. Fortescue, London, I 57 I, bk. 2, chap. 14 .

38. Of the three fifteenth-century Byzantine histories of Timur those of Ducas and Phranzes remained relatively inaccessible in MS until the seventeenth century. That of Chalcondylas was available and probably consulted by Marlowe (see Ellis-Fermor, U. M., op. cit., p. 23 seq).

39. Dyce, A., The Works of Christopher Marlowe . . , 3 vols., London, William Pickering, 1850, vol. I,

40. Hammer-PuRgStall, J., op. cit., vol. in, bk. vir, p. 4.

4I. Pearson, K., Nettreship, E., and Usher, G. H., A Monograph on Albinism in Man (Draper's Company Research Memoirs, Biometric Series VIII), University of London, 1913, vol. 1, p. 161.

42. Wolff, J., Travels and Adventures of the Rev. Joseph Wolf, London, Saunders, Otley \& Co., I86r, p. 580 .

43. Most contemporary histories of Timur mention his lameness although they differ as to how his disabilities were obtained. His sympathetic biographers refer to wounds sustained as a young man in the fighting at Seistan; Arabshah and Chalcondylas to injuries while sheep-stealing. They agree that it was his right side that was damaged.

44. In I94I Timur's sarcophagus, as well as those of his son Shahrukh and grandson Ulegbek, were sent to the Central Asian State University at Tashkent where their contents were examined. I am obliged to Mr. A. Obidin, Secretary, U.S.S.R.-Great Britain Society, for the information I have used in the text.

45. Pearson, K., et al., op. cit., p. 330, refers to red-haired albinos as a separate phenotype which he calls 'rufous albinos'.

46. Fol Ke R, K., A strange case of albinism, Lancet, 1879, i, 795.

47. St Annus, H. S., Pigmentation amongst natives in Nyasaland, Biometrika, 1913, 9, 333-66.

48. Frog G t t, P., Albinism in Northern Ireland, Ann. Human. Genet. (Lond.), 196o, 24, 214 .

49. PeARSON, K., et al., op. cit., p. 7.

50. WAFer, L., $A$ New Voyage and Description of the Isthmus of America, edited by G. P. Winship, Cleveland, Burrows Bros. Co., 1903. Relevant passages are quoted in full in Harlan, H. V., White Indians of Panama, J. Hered., 1932, $23,319-22$.

5I. Frog GAtT, P., op. cit., p. 215.

52. Seligmann, G. G., Albinism amongst Polynesians and Melanesians, Lancet, 1902, ii, 803-5. 


\section{P. Froggatt}

53. Pearson, K., et al., op. cit., vol. II.

54. Sanders, J., Die Heredität des Albinismus, Genetica, 1938, 20, 97-120.

55. Barnicot, N. A., Albinism in South-West Nigeria, Ann. Eugen. Lond., 1952, I 7, 38-73.

56. Froggatt, P., op. cit., appendix III.

57. MAnn, I., Developmental Abnormalities of the Eye, 2nd ed., London, B.M.A., 1957, p. 142.

$$
\mathbf{z} \overline{\mathbf{A}} \mathbf{L}
$$

I. Some thousand couplets were written by a tenth-century contemporary, Daqiqi, and are incorporated by Ferdusi. For more detail see Browne, E. G., op. cit., vol. I, p. 460.

2. Written for the Governor of Tus by four Zoroastrians in A.D. 957.

3. FIRD A USI, The Shdh Nameh, translated and abridged by J. Atkinson, London, 1832.

4. Robinson, S., Persian Poetry for English Readers, translated by S. Robinson for private circulation, Glasgow, privately printed, 1883 .

\section{EDWARD THE CONFESSOR}

1. Stanley, A. P., Historical Memorials of Westminster Abbey, $3^{\text {rd }}$ ed., London, Murray, 1869, p. 13.

2. Freman, E. A., History of the Norman Conquest of England, 2nd ed., Oxford, Parker, 1870, vol. II, p. 27.

3. Hunt, W., Dictionary of National Biography, London, I889, vol. xvIn, p. 8.

4. Ghu r chil , W. S., A History of the English-speaking Peoples, London, Educational Book Co., 1956, vol. I, p. I14.

5. LUARD, H. R., Chronicles and Memorials of Great Britain and Ireland during the Middle Ages: Lives of Edward the Confessor, edited by H. R. Luard, London, I 858, p. 387 .

6. Grozir R, G. J., A Study in the Life of Edward the Confessor. Thesis for the Master in Arts Degree, Queen's University, Belfast, 1937.

7. These are considered in detail in Luard, H. R., op. cit., pp. Xxm seq.

8. This chronicle is fully analysed in Crozier, G. J., op. cit.

9. Rов E R Ts, J . A. F., An Introduction to Medical Genetics, London, Oxford University Press, 1959, pp. $4^{1}$ seq.

\section{APPENDIX 1}

I am indebted to Dr. R. H. Harte, Principal, Belfast High School, for the translation of the following passages, the second of which appears in the text.

Perondinus, P. (1553), ch. 2 I.

Statura fuit procera et eminenti, barbatus, latus ab humerus et pectore, caeterisque membris aequalis et congruens integra valetudine, excepto altero pede, quo non perinde valebat, ut inde claudicare ac deformiter incedere propiceretur, oris truculenti atque obductae suae frontis oculi introrsus recedentes praeferocis animi sui saeuitiem spirantes intuentibus terrorem et firmidinem incutiebant, valida erat usque adeo neruorum compage, ut validissimum quemque e Scythia in palestra prosterneret, ac Parthici ingentis arcus chordam lacertosis brachiis ultra aurem facile posset extendere, aenumque mortarium excussi iaculi spiculo transfodere.

He (Timur) was tall and thin, bearded, broad-chested and broad-shouldered, symmetrical and sound in all his limbs except for one foot which was not as strong as the other so that as a 


\section{The Albinism of Timur, Zäl, and Edward the Confessor}

result he was seen to limp and to walk awkwardly. His eyes deep-set in a stern countenance and frowning brow expressing the ferocity of his haughty spirit struck terror and dread into those who beheld him. He had a frame so strong and sinewy that in the wrestling ground he threw the strongest of the Scythians, and by his muscular arms he was able easily to draw the string of the huge Parthian bow beyond his ear and to pierce the front of a brass helmet with the point of the arrow thus delivered.

Vita AEduardi Regis from MS. 526 in the Harleian collection, British Museum, and reproduced in Chronicles and Memorials of Great Britain and Ireland during the Middle Ages: Lives of Edward the Confessor, edited by H. R. Luard, London, 1858 .

Line 246 seq.

Et ut statum sive formam ejusdem non praetereamus, hominis persona erat decentissima, discretae proceritatis, capillis et barba canitie insignis lactea, facie plena et cuta rosea, manibus macris et niveis, longis quoque interlucentibus digitis, reliquo corpore toto integer et regius homo. Continua gravitate jocundus, humiliatis incedens visibus gratissimae cum quovis affabilitatis. Si ratio aliquem susciterat animi, leonini videbatur terroris, iram tamen non prodebat jurgiis.

\section{APPENDIX 2}

GeneAlogical data of the period are not always consistent. In compiling the accompanying pedigree I have relied on the authority of:

(a) William of Malmesbury. Chronicle of the Kings of England. Translated by J. A. Giles. London: Henry G. Bohn, 1847.

(b) Edited by A. Campberl. The Encomium Emma Reginae. Camden Third Series, vol. LxxII. London: Royal Historical Society, 1949.

(c) Freeman, E. A. History of the Norman Conquest. (See Bibliography.)

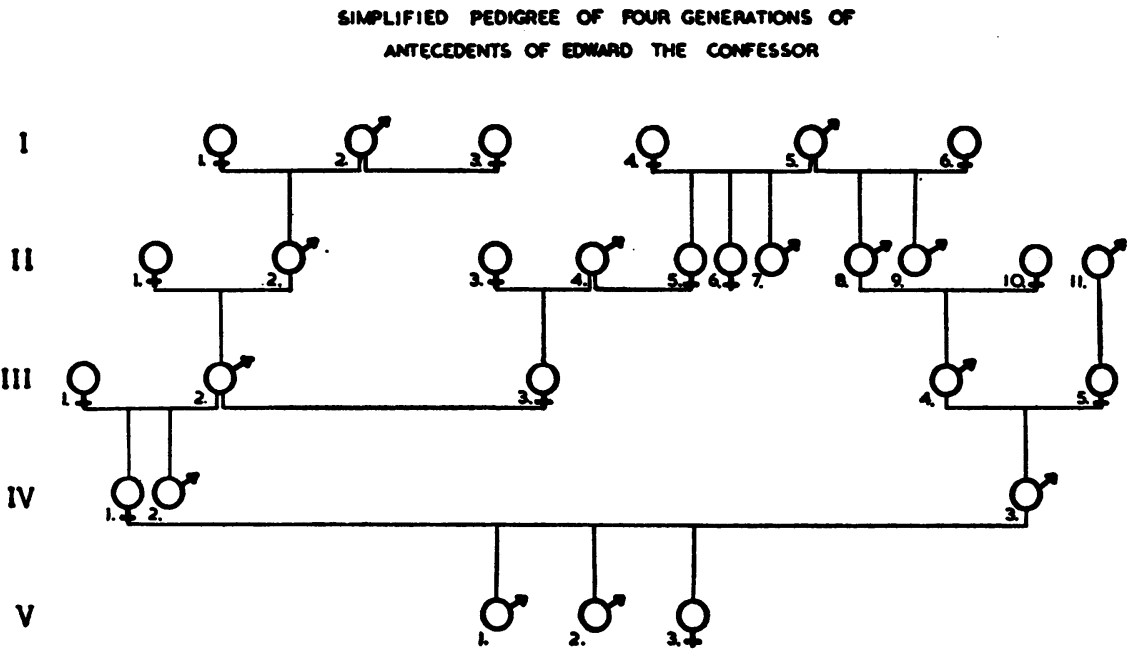

Explanation of Pedigree

I. I. Popa. First 'wife' of Rollo. Of Danish extraction.

I.2. Rollo. Of Viking extraction. Traditional founder of Normandy.

I.3. Gisela. Illegitimate daughter of Charles III of France.

I.4. Aelflaed. Second wife of Edward the Elder.

I.5. Edward the Elder. Son of Alfred the Great.

I.6. Edgifu. Third wife of Edward the Elder. Of pure Saxon descent. 


\section{P. Froggatt}

II.1. Sprota. Of Norman descent.

II.2. William Longsword. Duke of Normandy.

II.3. Hadwig. Sister of the Emperor Otto the Great.

II.4. Hugh the Great. Father of Hugh Capet, founder of the royal Capetian dynasty.

II.5. Eochild. Pure Saxon descent.

II.6. Eadgifu (Odgiva). Second wife of Charles III of France.

II.7. Eadwine.

II.8. Edmund the Magnificent. King of England.

II.9. Edred. King of England.

II.10. Aelgifu. Saxon descent.

II.11. Count Ordgar. Saxon descent.

III.1. Gunnor. Of Danish extraction. First 'wife' of Richard.

III.2. Richard I (the 'Fearless'). Duke of Normandy.

III.3. Emma. Second wife of Richard the Fearless.

III.4. Edgar. King of England.

III.5. Aelfthryth. Of Saxon descent.

IV.I. Emma (Aelgifu). Mother of Edward the Confessor.

IV.2. Richard II of Normandy.

IV.3. Ethelred the Unready. King of England.

V.1. Aelfred. Full brother of Edward the Confessor.

V.2. Edward the Confessor. King of England.

V.3. Godgifu. Full sister of Edward the Confessor.

\section{NEW LIGHT ON MANDRAKE}

IN an investigation undertaken in Delhi under the Ayurved Research Council of India, 'Lakshmana' has been found capable of controlling the sex of the prospective child.

Lakshmana is known to the medico as Mandragora Officinalun Linn. and is available in both the male and female varieties. The male shaped variety is used for begetting a son, and the female to produce a daughter, by administering it in the second month of pregnancy.

The sex of every unborn child, has hitherto been believed to be determined by $X$ and $Y$, two types of spermatozoa at the instant of conception.

After testing on thousands of cases results of the herb are ninety per cent, reported Dr. K. L. Khetal to the All India Ayurvedic (Medical) Conference, recently held in Delhi.

H. RAJ, Secretary 